\title{
Hypertension Risk Factor Control Effort In Post Stroke Patients
}

\author{
Yosi Suryarinilsih a), Hendri Budi, Netti, Wiwi Sartika \\ Politeknik Kesehatan Kementrian Kesehatan Padang \\ a)Corresponding Author: yosisuryarinilsih@gmail.com
}

\begin{abstract}
Post-stroke patients have risk factors for recurrent stroke. The main risk factor is hypertension. The purpose of this community service activity is to improve the ability of the community, especially poststroke patients, to control hypertension as a risk factor for recurrent stroke through identification of risk factors, health education and the application of light activity and deep breathing exercises. Before education is given, post-stroke patients and their families are given prestest first and after education, posttest returns to evaluate the patient's understanding. The results of the activity, there was a significant difference between the knowledge before and after being given education to post-stroke patients and their families with $p$ value $<0.05$. To the head of the room and the neuroscientific nurse, $d r$. M. Djamil Padang can continue the activity of identifying recurrent stroke risk factors and health education related to control of recurrent stroke risk factors in post-stroke patients by involving the Health Promotion (Promkes) department of Dr. M. Djamil Padang.
\end{abstract}

Keywords: recurrent stroke, hypertension, risk factors, post stroke

\section{INTRODUCTION}

Post-stroke patients can experience recurrent strokes. Repeated stroke is a matter of concern because it can worsen the general condition, increase treatment costs and increase the risk of death. A person with a history of stroke has a risk of recurrent stroke by $25-37 \%$ within 5 years after the first stroke, and the risk of death after stroke is around $45 \%-61 \%$. If repeated strokes occur again, it will be able to cause wider bleeding in the brain as a result, the patient's condition will be more severe than the initial attack and post-stroke patients who experience repeated strokes can experience disability and increase the occurrence of death/mortality (Rasyid, 2011).

The prevalence of stroke in Indonesia based on data from the 2013 Basic Health Research (Riskesdas) was 12.1 people diagnosed by health workers. West Sumatra is ranked 12th at $12.2 \%$. Recurrent strokes occurred in 19.9 percent of patients. In the city of Padang, Stroke ranks $15^{\text {th }}$, which is $8.4 \%$ (Kemenkes $\mathrm{Rl}, 2014$ ).

Hospital M. Djamil Padang is one of the largest hospitals in the city of Padang. The data obtained from the medical records of RSUP M. Djamil Padang in 2016, post-stroke patient visits at the neurology department of RSUP. M. Djamil always experienced an increase, including in 2013 as many as 1473 visits, 2014 as many as 1507 patient visits, and in 2015 as many as 1580 visits with the incidence of recurrent stroke as many as 292 people.

The high risk of recurrent stroke in post-stroke patients is related to controllable and uncontrollable risk factors. Risk factors that can be controlled include stress, hypertension, heart valve disease, diabetes mellitus, hypercholesterol, smoking, drinking alcohol, illegal drugs and oral contraceptives, while those included in risk factors that are not controlled include: age, gender, race and heredity (Junaidi, 2011). A case study conducted by Siswanto (2010) at Kariadi Hospital Semarang, found that there are 4 things that cause recurrent strokes in poststroke patients, namely: high blood pressure (systolic), blood sugar levels when above normal, heart abnormalities and irregularity with treatment (Amila, et.al, 2018)

One of the main risk factors that play a role in recurrent stroke is hypertension. Hypertension must be controlled by doing good treatment and control by the sufferer. Controlled hypertension can reduce the risk of recurrent stroke by $25 \%$ compared to 
uncontrolled hypertension (Andromeda, 2014). The results of research conducted at RSSN Bukittinggi showed that the highest risk factor for stroke was hypertension (95.8\%) (Budi, et al, 2017). Risk factors for uncontrolled hypertension after the first stroke can cause severe bleeding due to rupture of intracerebral blood vessels, causing suppression of the structure of the brain and blood vessels as a whole (Junaidi, 2011).

For this reason, it is necessary to control hypertension in post-stroke patients to avoid recurrent strokes. Efforts that can be made include identifying risk factors and their causes in post-stroke patients, providing education (Health Education) about risk factors for recurrent stroke and their management, and overcoming the increase in hypertension by doing light activities and deep breathing exercises. According to research conducted by Budi (2016), that deep breathing relaxation therapy in post-stroke patients can reduce systolic and diastolic blood pressure. The purpose of this activity is to improve the ability of the community, especially poststroke patients to control hypertension as a major factor in the occurrence of recurrent stroke.

\section{METHOD}

The target of this community service is the family and post-stroke patients who control the neurosurgery polyclinic of RSUP Dr. M. Djamil Padang. The method used in the implementation of this community service activity is 1). Carry out identification of risk factors for hypertension stroke in post-stroke patients through interviews and blood pressure measurements, 2). Carrying out health education through health education about efforts that can be made in controlling hypertension risk factors, starting with the pre test and after education, continuing with the post test, 3). Practicing light activities \& deep breathing that can be done by patients as an effort to control hypertension risk factors. Techniques for taking community service participants were all families and post-stroke patients who visited the neurosurgery polyclinic, Dr. M. Djamil Padang at the time the community service activities were carried out. The tools and materials used are tension meters. The extension media used was Power point which was presented using Infocus, and leaflets were provided which were distributed to all participants

\section{RESULTS}

The results of the anamnesis to identify the risk factors for stroke owned by post-stroke patients at the neurosurgery polyclinic of RSUP Dr. M. Djamil Padang data obtained that all poststroke patients have risk factors for hypertension (100\%). The results of the examination of blood pressure mean that the patient's blood pressure is $150 \mathrm{mmHg}$ (systolic), $85 \mathrm{mmHg}$ (diastolic), with a median of $150 \mathrm{mmHg}$ (systolic), 90 (diastolic), a minimum of 150180 (systolic) and 70-100 (diastolic). The results of data analysis showed that there was a difference in the average score of knowledge before and after being given education to poststroke patients $\&$ their families. Results of the bivariate analysis were $p<0.05$, which means that there was a significant difference between knowledge before and after education on risk factors for hypertension in patients and their families.

\section{DISCUSSION}

When viewed from the results of community service that has been carried out, it can be seen that all post-stroke patients who participate in this activity have a stroke risk factor, namely hypertension. Uncontrolled hypertension after the first stroke can cause heavy bleeding due to rupture of intracerebral blood vessels and cause blood to leak out of the blood vessels and enter the brain tissue so that the emphasis on the structure of the brain and blood vessels is overall, this will cause repeated strokes with an increased mortality rate, disability and the high cost of treatment due to recurrent stroke (Junaidi, 2011). The results of research conducted by Despitasari, (2020) said that there was a relationship between hypertension and the incidence of recurrent stroke in post-stroke patients with $p=0.002$.

If a person has a history of stroke accompanied by previous hypertension, and then does not control it well, then this will cause this patient to have recurrent strokes, and this can result 
in brainstem compression, brain hemispheres and secondary brainstem haemorrhage or extension of haemorrhage into the brain. Brainstem as the biggest complication resulting in death (Mutaqin, 2008). For this reason, efforts to increase knowledge and awareness of families and post-stroke patients on the importance and ways to prevent and control risk factors need to be done. In this community service activity, health education has been carried out to post-stroke patients and their families through health education about efforts to control risk factors for recurrent stroke and providing light activity exercises and breathing exercises, at the end of this activity families and patients do not forget to be provided with leaflets containing about stroke, risk factors for recurrent stroke and its prevention.

The evaluation results from this activity have shown that the knowledge of families and post-stroke patients has increased with very satisfactory evaluation results. This shows that the educational activities provided to patients can be well received by families and patients, and it also shows that with the implementation of health education through health education, the knowledge of families and post-stroke patients about efforts to control risk factors: hypertension in post-stroke patients to prevention of recurrent stroke increases. With good knowledge, it is hoped that the behavior of families and patients will be able to change for the better where families and post-stroke patients can modify their behavior by controlling their risk factors so that repeated stroke attacks can be avoided, because knowledge is important in achieving Changes in behavior, with high knowledge someone will try to apply it in real life.

In this community service activity, light activity exercises are also carried out on patients and also deep breathing exercises. According to lzzo (2008) one of the actions that can be taken to treat hypertension is relaxation and deep breathing. The results of research conducted by Budi (2016) that relaxation therapy and deep breathing performed for 15 minutes 2 times a day can reduce blood pressure in post-stroke patients.

The process of community service activities carried out did not encounter significant obstacles, hospital staff were able to accept the presence of the community service team well and nurses in the poly room also felt helped by these community service activities. Patients and families also seemed enthusiastic about listening to every direction given.

\section{CONCLUSIONS And RECOMMENDATIONS}

Community service activities that have been carried out on post-stroke patients and their families can provide good benefits and are able to increase patient and family knowledge about risk factors for hypertension to recurrent stroke and how to overcome them after patients and families are given health education. To the head of the room and nurses who work in the neurology department, they can continue the identification of risk factors and health education about efforts to control risk factors to avoid recurrent strokes in post-stroke patients and make this activity a routine program for the neurology department of RSUP Dr. M. Djamil Padang by involving the health promotion department in the hospital.

\section{ACKNOWLEDGMENTS}

Praise and gratitude we always pray for the presence of Allah SWT with His grace and permission, so that our community service team, majoring in nursing, Poltekkes, Ministry of Health, Padang, can complete this community service activity. This activity can be carried out with the help and support of various parties, because the authors express their gratitude to 1) Director of Poltekkes, Ministry of Health, RI Padang, 2) Director of RSUP Dr. M. Djamil Padang, 3) Head of the neurosurgery polyclinic, Dr. M. Djamil Padang. Hopefully this community service activity can be useful for the whole community and can improve the health status of the comunity

\section{REFERENCES}

Amila, Janno Sinaga end Evarina Sembiring. 2018. Pencegahan stroke berulang melalui pemberdayaan keluarga dan modifikasi gaya hidup. Journal Abdimas, universitas 



https://journal.unnes.ac.id/nju/index.php/abdimas/article/view/15808 (01/2/2019)

Andromeda, Ayu A. 2014. Hubungan hipertensi tidak terkontrol dengan kejadian stroke ulang di RSUD Sukoharjo. Melalui http://eprints.ums.ac.id/id/eprint/28056 (6/10/2019)

Budi, Hendri dan Reflita. 2016. Pengaruh Relaksasi Nafas Dalam Terhadap Penurunan Tekanan Darah Pada Pasien Pasca Stroke Di Poli Saraf RSUP Dr. M. Djamil Padang. Penelitian Risbinakes.Perpustakaan Poltekkes Kemenkes Padang

Budi, Hendri dan Idrawati. 2017. Faktor resiko stroke Hemoragic pada usia produktif. Jounal Sehat Mandiri 12(Desember). E Jounal online. Melalui http://jurnal.poltekkespadang.ac.id/ojs/index.php/jsm/article/view/97/33 (20/3/2018)

Despitasari,Lola. 2020. Hubungan Hipertensi dengan Kejadian Stroke berulang pada Pasien Pasca Stroke 2020. MIDWINERSLION: Jurnal Kesehatan STIKes Buleleng 5 (Maret). E Jounal Online. Melalui: http://ejournal.stikesbuleleng.ac.id/index.php/Midwinerslion/article/view/141 (1/5/2020)

Izzo, Joseph, Sica, Domenic, et.al. 2008. Hypertension Primer: The essential of High Blood Pressure Basic Science. Population Science, and Clinical Management, Edisi 4. Philadelphia. USA. Liipicont Williams \& Wilkins

Junaidi, Iskandar. 2011. Stroke Waspadai Ancamannya. Yogyakarta: CV Andi Offset

Muttaqin, Arif. 2008. Asuhan Keperawatan Klien dengan Gangguan Sistem Persyarafan. Jakarta: Salemba Medika

Rasyid, Al. 2011. Unit stoke: manajemen stroke secara komprehensif. Jakarta: Balai Penerbit Fakultas Kedokteran Universitas Indonesia. 

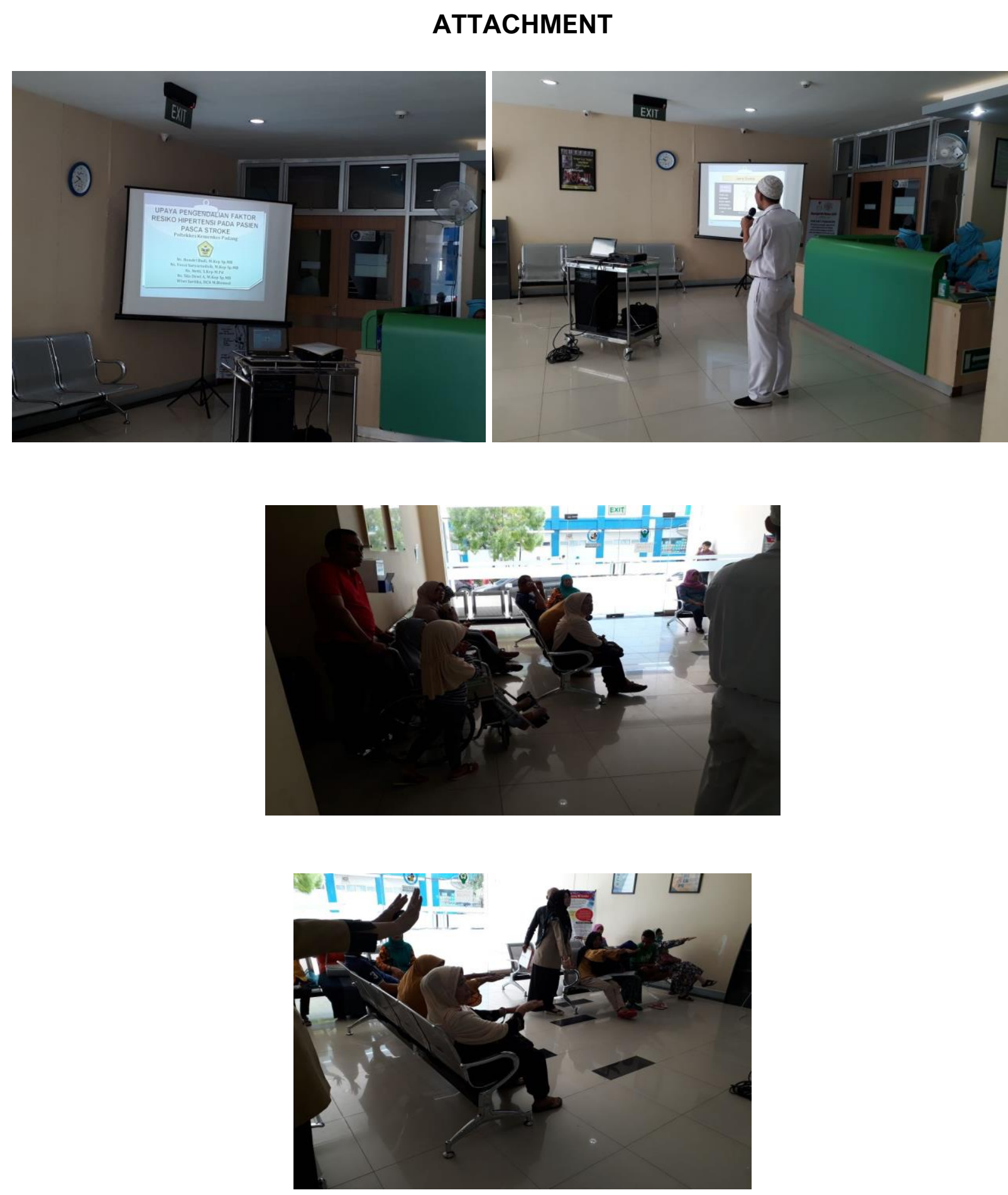


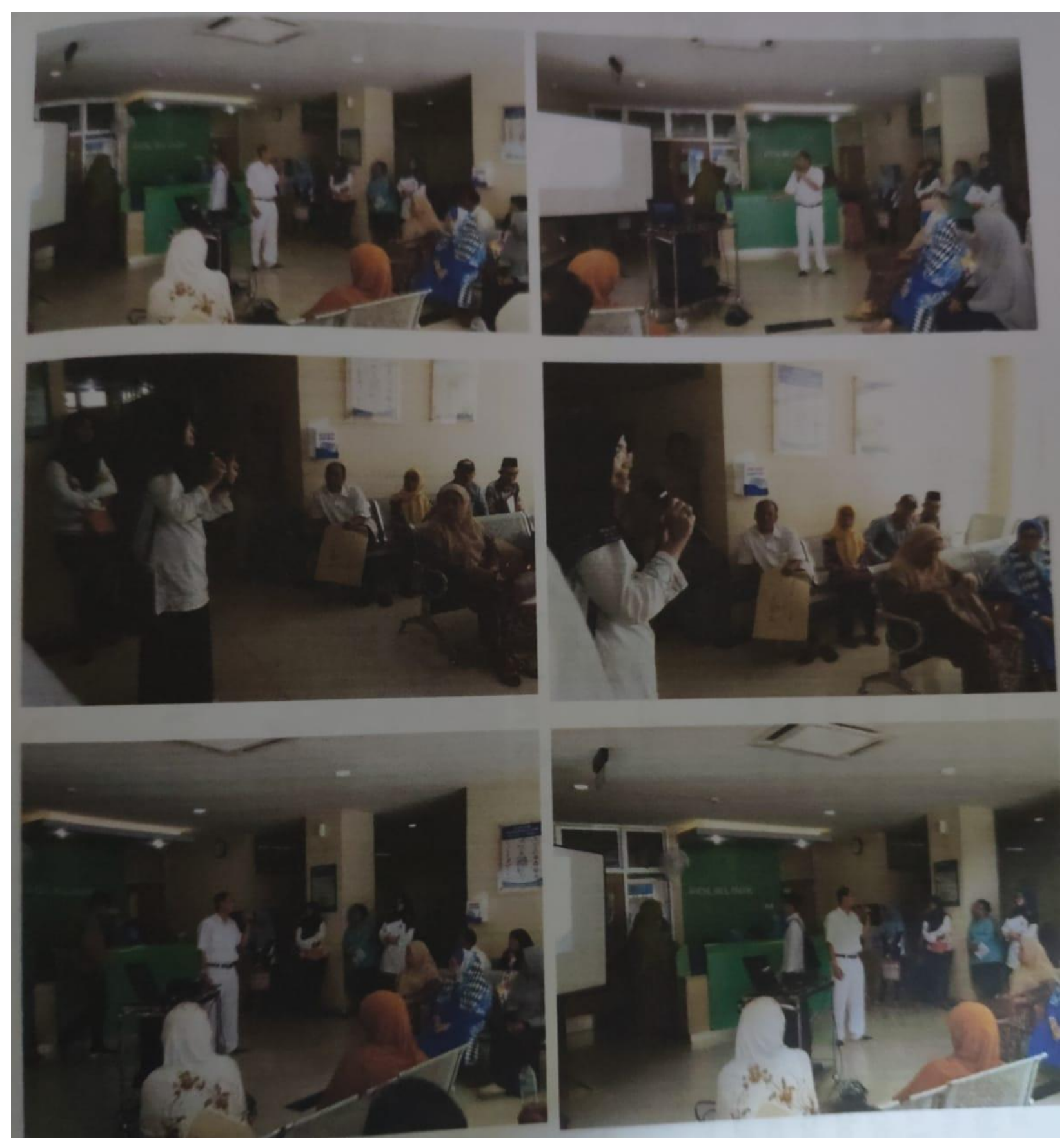

Documentation 